\title{
Harm and benefit of Khibiny mining waste
}

\author{
Olga Krinochkina ${ }^{1}$, Dinya Mamina ${ }^{1,}$, and Vladislav Stulov ${ }^{2}$ \\ ${ }^{1}$ Moscow State University of Civil Engineerin, Moscow, Russia \\ ${ }^{2}$ LabWare LLC, Moscow, Russia
}

\begin{abstract}
The article is focused on the assessment of the impact of mining waste on the environment. Mining waste (MW) is understood as mine (mining) dumps and dumps of processing plants (tailings dumps). The article also suggests considering MW as technogenic deposits of rare earth and precious metals, the development of which will allow solving many environmental, social and economic problems and using natural resources in a sustainable manner. The objects under study are located on the Kola Peninsula, within the Khibiny mountain range, and are the production assets of the Apatit Mining Complex. This enterprise develops the so-called deposits of the Khibiny Tundra, it also owns apatite-nepheline processing plants.
\end{abstract}

\section{Introduction}

The relevance of the research topic is due, on the one hand, to the extremely large number of mineral deposits (MD) being developed in this country, and, on the other hand, is explained by the need for new approaches to protecting the natural environment, which is inevitably transformed during their development. According to the authors, when creating mining enterprises, it is necessary to take into account the specific features of the terrain and the potential response of the natural environment to man-made impacts. This opinion of the authors develops the ideas of M.I. Agoshkov, B.N. Laskorin, N.V. Melnikov, V.V. Rzhevsky, E. M. Sergeev, A.V. Sidorenko, N.F. Khachaturov, S.S. Shvarts, M.I. Glazovskaya, A.I. Perelman, S.N. Kasimov, R.V. Goleva and other domestic and foreign scientists. The current development level of mining production cannot be limited only to environmental actions of a protective nature [1]. It is necessary that such actions should rather be preventive and based on a scientific forecast. The latter should be based on an assessment of the interrelationships of the physical and chemical processes underlying the development of minerals on the one hand and natural conditions on the other.

\section{Materials and methods of research}

The research is based on the materials obtained during the implementation of the State Contract of the Ministry of Natural Resources of the Russian Federation "Assessment of changes in the quality of groundwater in the areas of mining enterprises as an indicator of

*Corresponding author: dmamina@mail.ru 
accumulated environmental damage". The objects of this research are the deposits of the Khibiny Tundra, the existing Kirovsky and Rasvumchorrsky mines, as well as apatitenepheline processing plants (ANOF-1, ANOF-2 and ANOF-3) and the zones of their impact. All these enterprises are production assets of JSC "Apatit" (Figure 1).

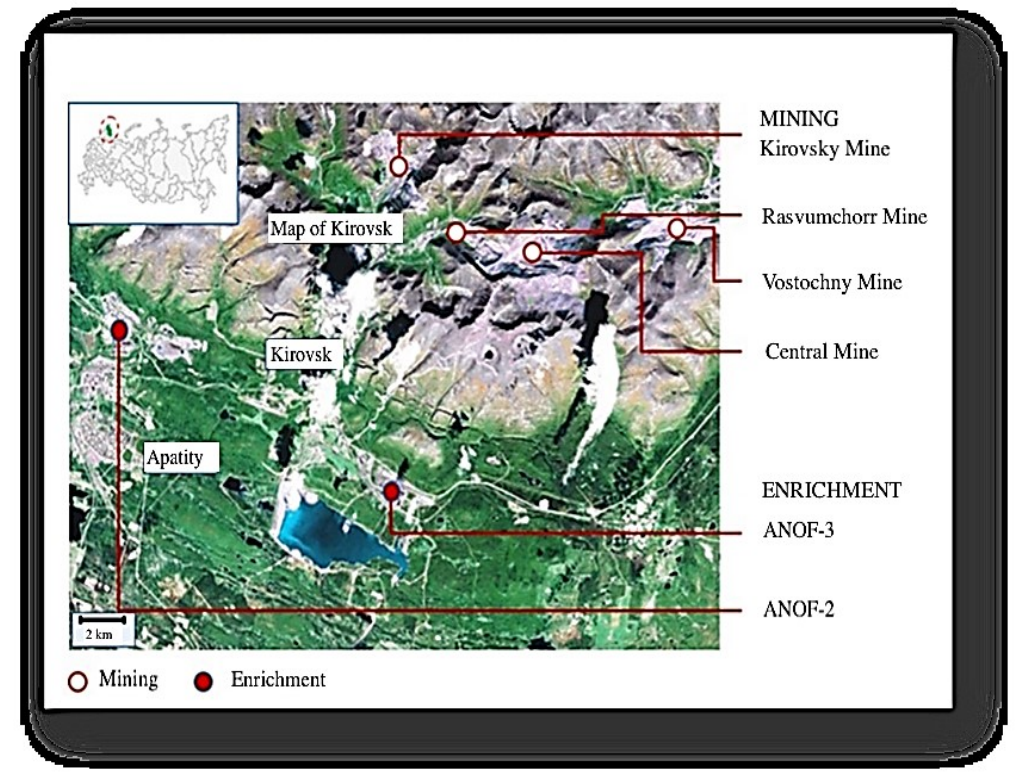

Fig. 1. Location of the objects of research within the area of the Apatit mining complex.

This group of deposits of the Kola Peninsula (Murmansk Region) is characterized by very large reserves of ores, a long period of their mining and a set of dangerous elements polluting the environment, such as rare, rare-earth and radioactive elements, as well as strontium , fluorine and other toxic elements.

The research methods included field observations, sampling (of soils, bottom sediments, surface and underground waters, ores and enclosing rocks, rock dumps by fractions), multiscale ecological and geochemical mapping, and office processing. The complex of laboratory studies included the following: approximate quantitative atomic emission spectral analysis for 40 elements (for samples of ores, enclosing rocks, mining dumps), atomic absorption for gross forms of mercury (in all samples) and mass spectrometric analysis with inductively coupled plasma for samples of underground and surface waters and mobile forms of elements for soils and bottom sediments (for 46 elements). Office processing of materials was carried out using software in the shell of Argis, Exel, Statistic.

The specific feature of this research methodology was the study of the composition of fractions (according to the particle size) in the mining dumps: mining dumps and tailings dumps (hereinafter referred to as dumps and tailings dumps).

The mine has been existing for more than 85 years. Average mineral composition of apatite-nepheline ore (\%) is as follows: apatite $(10-91.5)$, nepheline $(3.16-73.5)$, pyroxene $(3.21$ - 17.57), sphene (signs - 36.12). The content of the main components in the ore $(\%)$ is as follows: $\mathrm{P}_{2} \mathrm{O}_{5}-14.48 ; \mathrm{SrO}-1.18 ; \mathrm{Al}_{2} \mathrm{O}_{3}-14.23 ; \mathrm{Ga}-0.0015 ; \mathrm{Rb}_{2} \mathrm{O}-0.0095 ; \mathrm{SeO}-$ $0.0000025 ; \mathrm{TiO}_{2}-1.84 ; \mathrm{Nb}_{2} \mathrm{O}_{5}-0.16$ [2]. Such a long-term development of deposits associated with the above-mentioned material composition creates serious negative environmental changes. This is primarily due to the fact that due to the predominance of alkaline rocks in the region, the migration abilities of most toxic elements are greatly increased. Naturally, this is explained by sharp predominance of the ligand-ion of $\mathrm{OH}$. In addition, the alkaline dumps of ore deposits also contribute to the accumulation of such strong 
ligands-complexing agents, such as fluorine and organic substances, for example. All this activates the migration of many toxic elements into underground and surface waters.

Existing measures for the protection and recovery of the environment mainly include the purification of drain waters from suspended particles, petroleum products and nitrogen compounds. According to G.B. Melentyev [3], the environmental monitoring system installed within the mines and the area of operation of apatite-nepheline processing plants (ANOF-1,2,3) does not track the behavior of many toxic components, and therefore additional ecological and geochemical studies were conducted.

To assess the impact of tailings dumps and mining dumps on the environment, the authors carried out a complex of works in the studied area, including:

1) selection of geochemical samples from dumps, tailings dumps and from watercourses associated with dumps and tailings dumps;

2) separation of the debris material of dump samples into gain sizes $-5-2 \mathrm{~mm}, 2-1 \mathrm{~mm}$, 1-0.5 mm, 0.5-0.25 mm, 0.25-0.1 mm, 0.1-0.044 mm, 0.044-0.02 $\mathrm{mm}$ and less than $0.02 \mathrm{~mm}$ and tailings $-0.5-0.25 \mathrm{~mm}, 0.25-0.1 \mathrm{~mm}, 0.1-0.044 \mathrm{~mm}, 0.044-0.02 \mathrm{~mm}$ and less than $0.02 \mathrm{~mm}$ (separation of the debris material of dump samples into particle fractions was carried out using sieve and slurry techniques);

3) determination of the trace element composition of the samples by a set of methods, namely: the material of gain sizes in the dumps- by spectral semi-quantitative analysis (SSQA), and individual lithochemical and surface and underground water samples - by mass spectrometry (ICP MS and ICP OES).

Further processing of the obtained materials showed the proximity of the trace element composition of the conjugated size classes. Therefore, to simplify the procedure of the composition analysis, the classes were enlarged, i.e. combined in pairs $(5.0-1.0 \mathrm{~mm} ; 1.0-$ $0.25 \mathrm{~mm} ; 1.0-0.25 \mathrm{~mm} ; 0.044-0.02 \mathrm{~mm}$ and less than $0.02 \mathrm{~mm}$ ). But within the enlarged classes, the chemical composition showed significant differences, both in mine dumps and in tailings dumps.

\section{Research results}

Upon completion of the field observations, sampling and appropriate laboratory studies, as well as office processing of materials, the results were summarized in Table 1.

Table 1. Summarized results.

\begin{tabular}{|c|l|}
\hline \multicolumn{2}{|c|}{ Mine dumps } \\
\hline Particle size (mm) & \multicolumn{1}{|c|}{ Element associations } \\
\hline $5-1$ & B, Sc, Ti, Ba \\
\hline $1-0.25$ & B, Sc, Ti, Ba, $\mathrm{Cr})$ \\
\hline $0.25-0.044$ & $\mathrm{P}, \mathrm{Ga}, \mathrm{Cr}, \mathrm{Sr}$ \\
\hline$<0.044$ & $\mathrm{Cu}, \mathrm{Pb}, \mathrm{Zn}, \mathrm{Be}, \mathrm{Y}, \mathrm{Yb}, \mathrm{Sc}, \mathrm{Zr}, \mathrm{Nb}$ \\
\hline $\begin{array}{c}\text { Concentration not } \\
\text { expressed }\end{array}$ & $\mathrm{Ce}, \mathrm{La}, \mathrm{Su}, \mathrm{As}, \mathrm{Ag}, \mathrm{Co}, \mathrm{Ni}, \mathrm{V}, \mathrm{Mn}$ \\
\hline \multicolumn{2}{|c|}{$\mathrm{Tailings}$ dumps } \\
\hline Particle size (mm) & \\
\hline $1-0.25$ & $\mathrm{~B}, \mathrm{Sc}, \mathrm{P}, \mathrm{Mo}$ \\
\hline $0.25-0.044$ & $\mathrm{Nb}, \mathrm{Ga}, \mathrm{Zn}, \mathrm{V}, \mathrm{Mn}, \mathrm{Ti}$ \\
\hline
\end{tabular}


Table 1. Continued.

\begin{tabular}{|c|l|}
\hline$<0.044$ & $\begin{array}{l}\mathrm{Pb}, \mathrm{Zn}, \mathrm{Cu}, \mathrm{Co}, \mathrm{Mn}, \mathrm{Y}, \mathrm{Yb}, \mathrm{Ce}, \mathrm{La}, \mathrm{P}, \mathrm{Ti}, \mathrm{V}, \mathrm{Cr}, \\
\mathrm{Be}, \mathrm{Sn}, \mathrm{As}, \mathrm{Sr} \mathrm{Nb}\end{array}$ \\
\hline $\begin{array}{c}\text { Concentration not } \\
\text { expressed }\end{array}$ & $\mathrm{Zr}, \mathrm{Ag}, \mathrm{Ni}, \mathrm{Ba}$ \\
\hline
\end{tabular}

As follows from the Table, one can observe significant variations in the distribution of element concentrations across the combined groups of fractions of detrital material [4] of mining dumps and tailings dumps.

When comparing the trace element compositions of particle sizes in the mine dumps, attention is drawn to the identity of the associations of accumulation elements $(\mathrm{B}, \mathrm{Sc}, \mathrm{Ti}$, $\mathrm{Ba})$ in the two largest sizes $-5.0-1.0 \mathrm{~mm}$ and $1.0-0.25 \mathrm{~mm}$. The next largest class $(1.0-$ $0.25 \mathrm{~mm}$ ) is also characterized by the concentration of a relatively small number of elements $-\mathrm{P}, \mathrm{Ga}, \mathrm{Cr}$ and $\mathrm{Sr}$, while in the thinnest class $(0.044-0.02 \mathrm{~mm}$ and less than $0.02 \mathrm{~mm}$ ) their number increases significantly.

Tailing dumps as a whole are also characterized by growth of the accumulation of the number of chemical elements in fine grain sizes. $\mathrm{Cu}, \mathrm{Pb}, \mathrm{Zn}, \mathrm{Co}, \mathrm{Mn}, \mathrm{Y}, \mathrm{Yb}, \mathrm{Ce}, \mathrm{La}, \mathrm{P}$, $\mathrm{Ti}, \mathrm{V}, \mathrm{Cr}, \mathrm{Be}, \mathrm{Sn}, \mathrm{As}, \mathrm{Sr}, \mathrm{Nb}$ are concentrated here, so the number of accumulation elements is greatly higher than in a similar association of the mining dumps [5].

The noted similarities and differences in the trace element compositions of fine grains in the tailings dumps and rock dumps can be associated both with the primary natural enrichment of rocks and ores with certain elements, and with the features of the enrichment technology of processed ores [6].

Intensive enrichment of fine grains of dumps and tailings with various chemicals, including toxic elements (TE), determines interest in them as the most likely and active sources of pollution of natural waters and the environment as a whole on the one hand, and as technogenic deposits of these elements on the other hand. At the same time, it is natural that the pollution occurs more intensively during the migration of elements from tailings dumps, which is due, firstly, to higher concentrations of TE here, and secondly, due to disintegration of the material here, its active contact surface with the host medium is increased. The high intensity of the TE migration from them is attributed to active interaction of water and debris due to its intensive grinding. Thus, when comparing the stale "tails" from ANOF-1 enrichment (recultivation was carried out only by seeding plants) and the modern "tails" of the ANOF-2 processing plant, it was discovered found that the content of toxic elements such as beryllium, plumbum, arsenic $(\mathrm{Be}, \mathrm{Pb}, \mathrm{As})$ decreases several times over the years (Figure 2). It is clear that these elements mainly penetrate into natural waters, i.e. they are potential pollutants of surface and underground waters in the area of activity of JSC Apatit. 

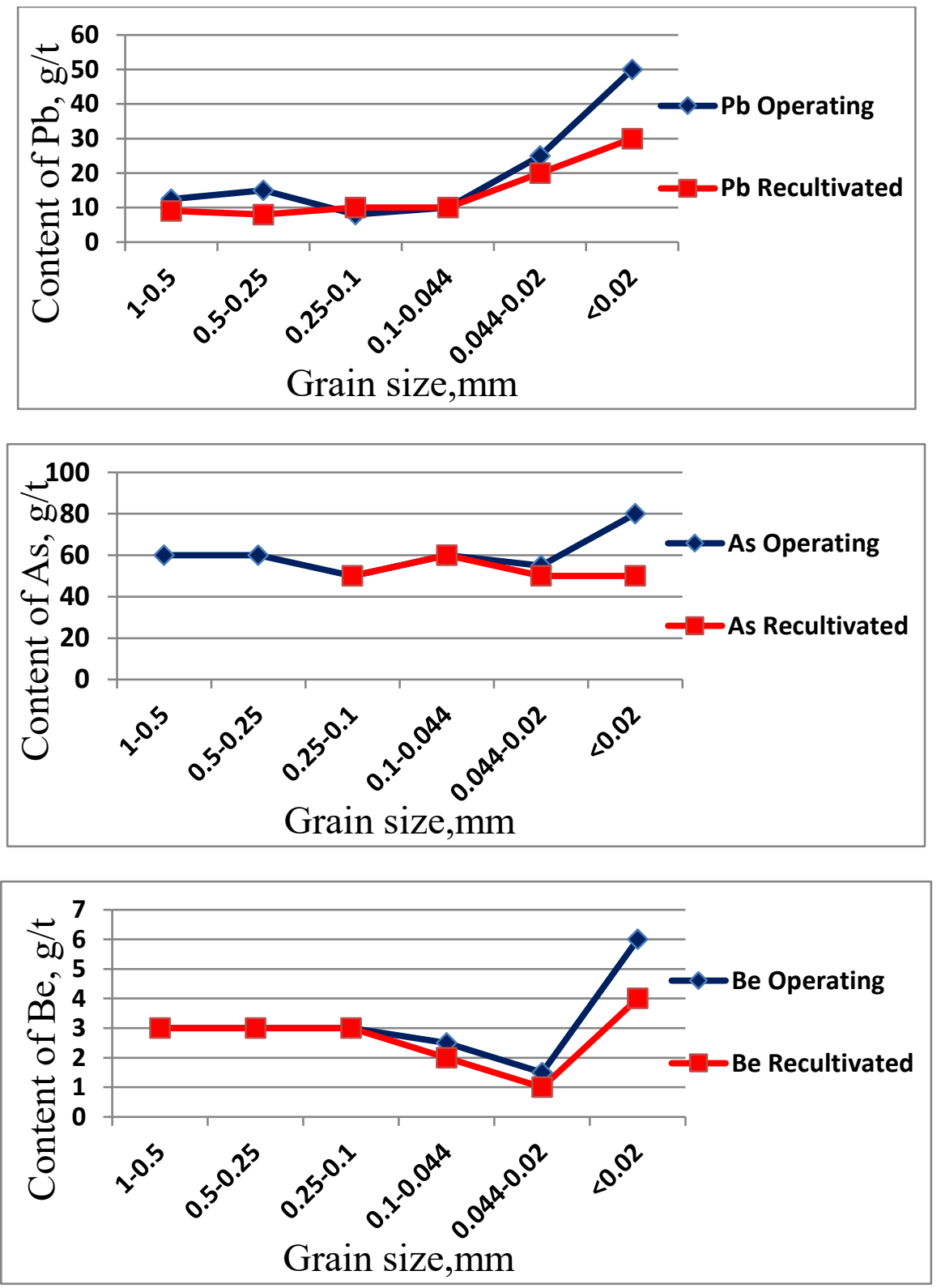

Fig. 2. Grain distribution of several toxic elements in the existing and recultivated tailings dumps [7].

According to monitoring data in the of ANOF-1 impact zone (recultivated tailings storage) in the underground waters of the peat-marsh and technogenic aquifers, arsenic and plumbum concentrations exceeding the background ones by 1.5-2 times are observed in individual samples. Within the ANOF-1 impact zone (the operating tailings storage facility), background excess for the same components is more often found in surface water reservoirs, which is most likely due to dusting of loose dumps.

Let us now consider the fine particles of mining waste from the deposits of the Khibiny Tundra as a concentrate of rare, rare-earth (REM) and precious metals. The first in the list is gold. It was first found by the authors in individual samples of MW in concentrations 
up to 3-4 g/t according to the SSQA data, and, according to mass spectrometric analysis (ICP-MS), it was $0.1-0.2 \mathrm{~g} / \mathrm{t}$. It should be noted that gold is characterized by an extremely uneven distribution.

An idea of the content (concentrations) of the main REM gains can be obtained from Figure 3.
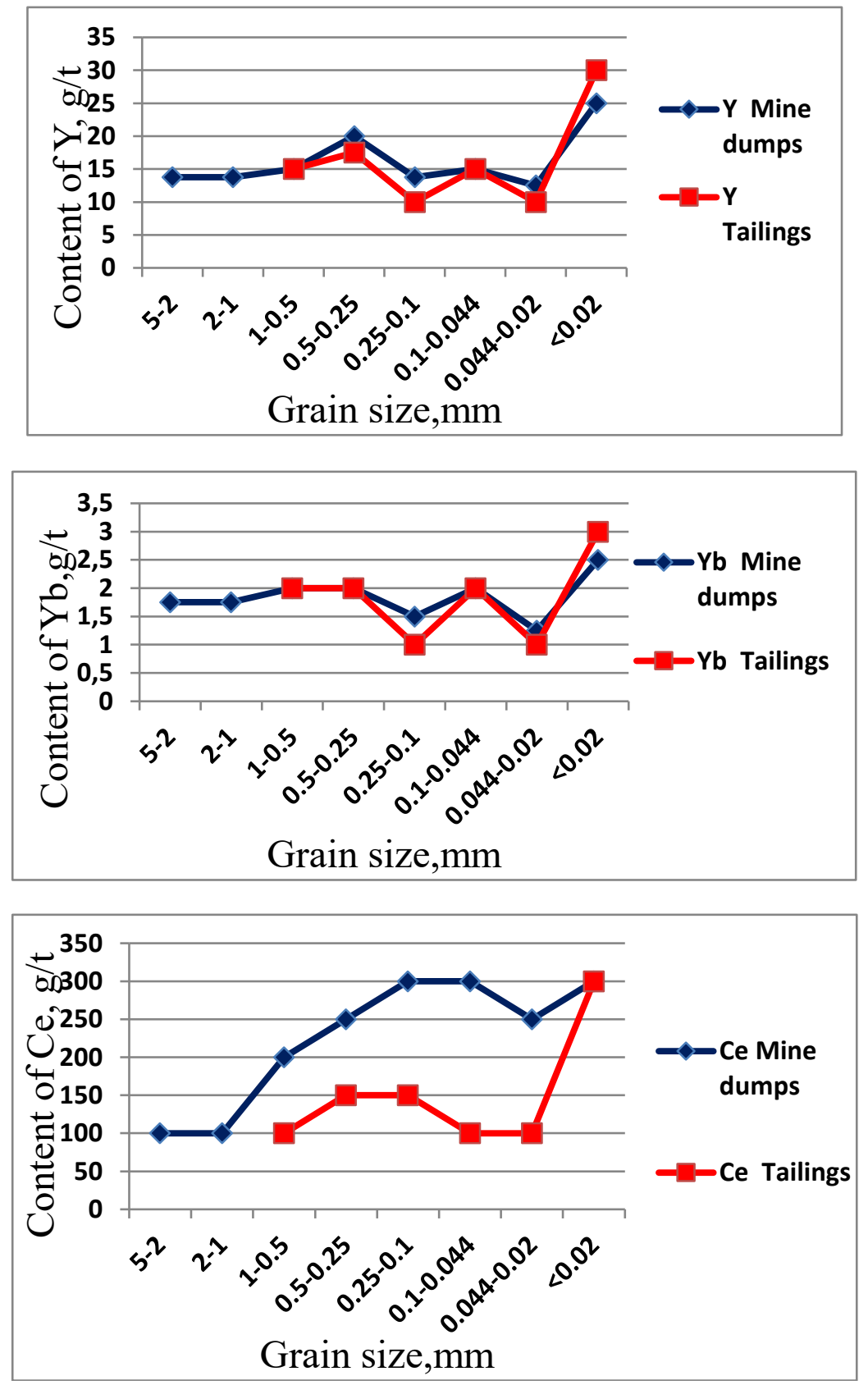


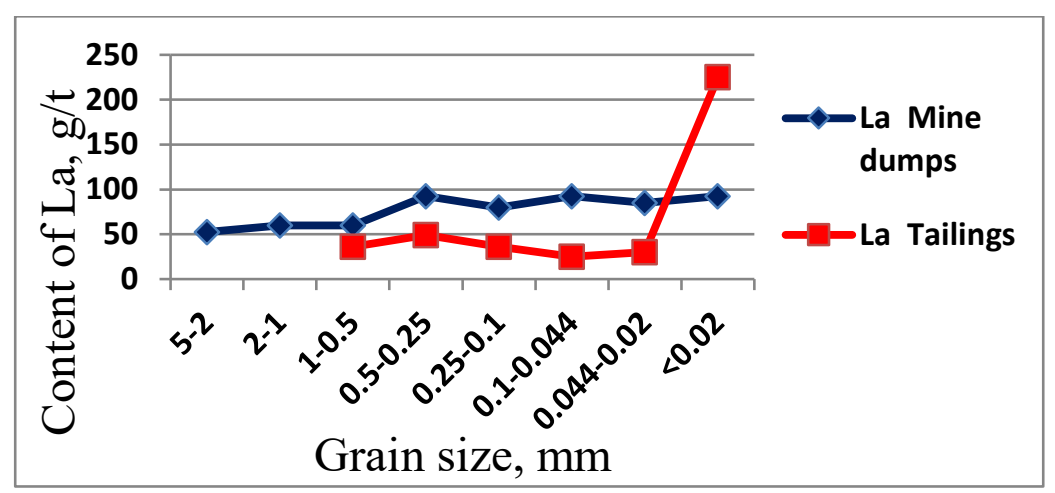

Fig. 3. Average concentrations of some rare-earth elements in the isolated fractions of the Khibiny mining dumps and tailings dumps $(\mathrm{g} / \mathrm{t})$.

As can be seen from the accumulation series (see Table 1 - The associations of elements are arranged in rows in descending order of their concentration coefficients) and the graphs above, cerium is found in the largest quantities of REM (according to the authors' data, Ce content is up to $300 \mathrm{~g} / \mathrm{t}$ ), then goes lanthanum (up to $220 \mathrm{~g} / \mathrm{t}$ ), and together they total $520 \mathrm{~g} / \mathrm{t}$. Next comes yttrium and elements of the yttrium group, and these metals are two or even three orders of magnitude more expensive than the more common metals of the cerium group [8].

Below is some data on the presence of REM in various large deposits of Kazakhstan:

- the Zhanatas deposit has an average $\sum$ REM content of $614 \mathrm{~g} / \mathrm{t}$, including yttrium $300 \mathrm{~g} / \mathrm{t}$, ytterbium - $4.2 \mathrm{~g} / \mathrm{t}$, cerium - $110 \mathrm{~g} / \mathrm{t}$, lanthanum $-200 \mathrm{~g} / \mathrm{t}$;

- the Aksai deposit has an average $\sum$ REM content of $938 \mathrm{~g} / \mathrm{t}$, including: yttrium $440 \mathrm{~g} / \mathrm{t}$, ytterbium $-440 \mathrm{~g} / \mathrm{t}$, cerium $-210 \mathrm{~g} / \mathrm{t}$, lanthanum $-280 \mathrm{~g} / \mathrm{t}$;

— in the field Chulaktau the average content of $\sum R E M$ is $1088 \mathrm{~g} / \mathrm{t}$, including: yttrium $-520 \mathrm{~g} / \mathrm{t}$, ytterbium and $8.1 \mathrm{~g} / \mathrm{t}$, cerium $-250 \mathrm{~g} / \mathrm{t}$, lanthanum $-310 \mathrm{~g} / \mathrm{t}$;

- the Kokjon field has an average content of $\sum$ REM $63 \mathrm{~g} / \mathrm{t}$, including: yttrium $312 \mathrm{~g} / \mathrm{t}$, ytterbium - $5.5 \mathrm{~g} / \mathrm{t}$, cerium - $138 \mathrm{~g} / \mathrm{t}$, lanthanum $-175 \mathrm{~g} / \mathrm{t}$;

- the Koksu deposit has an average $\sum$ REM content of $700 \mathrm{~g} / \mathrm{t}$, including: yttrium $376 \mathrm{~g} / \mathrm{t}$, ytterbium $-6.3 \mathrm{~g} / \mathrm{t}$, cerium $-166 \mathrm{~g} / \mathrm{t}$, lanthanum $-152 \mathrm{~g} / \mathrm{t}$.

When comparing the above data, the conclusion arises that it is necessary to consider the Khibinsky MW as promising technogenic deposits of REM and gold. Using this resource, several environmental, social and national economic tasks are addressed at once. And namely: minerals are extracted from the end concentrate, public employment rises due to the creation of new jobs, and mining waste that have polluted the environment for many years is disposed of. Of course, a lot of work is needed to develop a technology for extracting valuable metals, studying their mineralogical and metallogenic features, but given an extremely high demand in them, this will significantly increase the role of MW as a valuable natural resource, including this resource in complex technological chains of processing apatite-nepheline ore. The disposal of MW will improve the environmental situation in the region under consideration

\section{Conclusions}

Toxic elements concentrated in the MW, and especially in the material of small fractions (less than $0.044 \mathrm{~mm}$ ) of mine dumps and tailings dumps can become a source contamination source of the environment. 
1. Geochemical assessment of the grain size fractions of the MW material can be used to predict the potential threat of environmental contamination from the operation of mining enterprises.

2. The results obtained indicate the possibility of identifying a unique technogenic deposit of rare earth metals (REM) with gold within the Khibiny mining area, as well as the need for revaluation of MW with their involvement in processing. As is known, about $82 \%$ of the balance reserves of REM are apatite ores, and more than $70 \%$ of the reserves are associated with apatite-nepheline ores of the Khibiny Tundra deposits. However, they are still not extracted from the ores mined there. The only exception is the Lovozerskoye deposit field. In the remaining deposits of the Khibinsky group, REM remains in the tailings of enrichment. Although it is estimated that their extraction is quite cost-effective. Complex processing of all apatite raw materials would allow producing about 40 thousand tons of rare earth per year. According to the authors' calculations, the reserves of cerium (Ce) alone in the tailings of ANOF-2 enrichment plant are worth about 150 thousand tons (it should be noted that there are much more $\mathrm{Ce}$ in mine dumps). In addition, these reserves are in the form of finely dispersed fractions, i.e. it is a ready-made "concentrate" of gold and REM. All this is especially relevant now, when REM is extremely demanded by the industry.

\section{References}

1. M. Pevsner, V. Kostovetsky, Ecology of mining production (1990)

2. S. Ikorsky, V. Nivin, V. Pripachkin, Geochemistry of gases of endogenous formations (1992)

3. G. Melentyev, O. Vdovina, E. Malinina, I. Karimova, A. Popova, Proceedings of the collection of scientific articles of the regional scientific and practical jubilee conference on November 13-15, 93 (2013)

3. G. Melentyev, O. Vdovina, E. Malinina, I. Karimova, A. Popova, Collection of scientific articles of the regional scientific and practical jubilee conference on November 13-15, 93 (2013)

4. O. Vdovina, K. Naumov, N. Stulova, Collection of scientific articles of the regional scientific and practical jubilee conference on November 13-15, 123 (2013)

5. I. Spiridonov, O. Vdovina, K. Naumov, R. Vysokinskaya. Proceedings of the of the XIII International Conference, 25 (2014)

6. P. J. Beckett, S. Pappin-Willanen, G. M. Courtin, Proceedings of the ISGE (GEOENV'97) Istanbul, Turkey, 252 (1997)

7. O. Vdovina, A. Lavrusevich, G. Melentyev, I. Evgrafova, K. Naumov, D. Yelchin, K. Polyakova., E. Shubina, MGSU Bulleten, 12, 152 (2014)

8. O. Krinochkina, V. Ivanov, Proceedingof the All-Russian Conference, 107 (2016) 